\title{
恙虫病の免疫に関する研究 $(\mathbb{I})$
}

抗生物質で早期に解熱させ了つけ接種恙虫 病後の免疫に就いて *

中 村 清**

\section{KIYOSH NAKAMURA: STUDY ON THE IMMUNITY AGAINST TSUTSUGAMUSHI DISEASE}

[受稿 4尺11日 1956]

\section{緒}

\section{言}

恙虫病の免疫心関しては，従来多くの研究が行われ て来な，殊にその先疫予防法としては実に多くの試み 艻存されて来なが，大别すると生病毒学以ての子防接 種》，ワクチンによるもの，及び最近の抗生物質投与

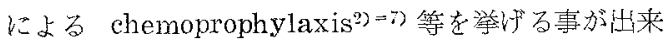
る.

私は此の問題に就いて実験を続けて居るがその一部 として既に第 1 報》に拾いて人体に於ける病毒の侵入 量と発病との関係，発病時の血中病毒量，及びそれら と免疫生成との関係等に就いて報告した。

本病の発病の程度と免疫生成の程度との関係に就い ては，睤に川村等910りより定型的な発病を経過した 後には10年余にわたり强固な免疫が持続することが実 証されたが，一方，最近その著效性を以て広く治潦に 用いられている抗生物質により発病早期に解熱させら れな場合の免疫生成の程度及びその持続等に就いては 何等確実な知見吕得られて居ない。

Smadel 等10は，抗生物質治療を受けた恢復後の患 者に再接種攻㢣を行い，同一株のものでは1〜2力月後 も再感染に站し強固な抵抗を示したことを報告してい るが，その後の免疫持続に就いては観察して居ない。

亦，Ley 等”仗人聞に chemoprophylaxisにより 発病を来主ことなく免疫を与えることが出来，それは 1 カ月後の生病毒攻撃に耐えたと報告しているが，免 疫の持績に就いては触れていない。

他方，緒方(規) ${ }^{137}$ は，抗生物質投与により治檍した 自然感染㭧者が 1 年後, 自然再感染した例を 1 例举げ,
早期治瘾によつては充分な免没が出来ないと述へて居 亏.

私は，古等の間題の解明に就いて契験索績けて来な 方，今回は発病直後に抗生物質療法を開始して解熱さ せ了つた接種恙忠病患者の治瘾後 2 为年を経たもの 名，種々の量の再接種攻熬に站し，完全な免疫抵抗老

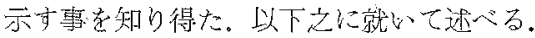

\section{実 験 材 料}

実験材料はすべて第 1 報》記戴のものと全く同様で あるが，重要な事であるから敢えて再度詳述する。

1. 病 : 澎湖島株恙虫病久毒走使用した。之は昭 和10年〔亿村等14)に依り澎湖島の㙅虫病患者より分離さ れ，爾後，新潟医大病理学教室を経て北里研究所病理 部で継代保存して居たが，終戦封の混乱に依り断絶し て仕舞つたのを，偶々その前に本病請接種に依る熱潦 法を受けた進行麻痺雇者の腋窎リンパ節より北里研觉 所の福住等吕 recover し，その後我々の研究室に於 いて昭和22年以降主としてマウス継代に依り保存され て居るものである。

2. 接種材料：上記病昰の一定量老腹院内に接種さ れ，定型的に発症し極期に在るマウス 3 匹よりその䀒 を集め，之を乳針内で硝子細粉と共に磨砾し，繗酸緩 㣫食塩水10倍稀釈脱脂乳液（Penicillin G 500u/ml, Streptomycin $1,000 \mu \mathrm{g} / \mathrm{ml}$ 加) で重量 $10 \%$ 乳㓩とし， 2,000 r. p. m. 10 分間遠沈し，その上清を10-1 稀僠液 とし，倍数稀釈の出発材料とした。稀翻にはすべて前 記の脱脂乳液学用いた。

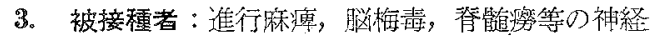

* 本論交の要旨注昭和31年4月6日第29回日本細菌学会総会（熊本）に於いて口演報告された。

并并精神医学研究所 (指導 林㙛 部長) 


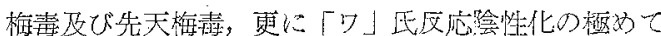
困難な梅毒患者に実際に前記病毒者以ての蒸察法学 施し，之に附随して諸検索を実施した。今回の实睮に

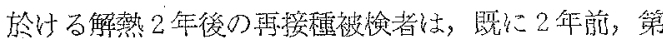
1 報》所報の如く接種恙虫病を経過した者である。

\section{実 験 方 法}

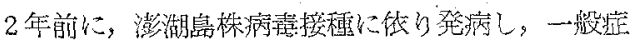
状及び rickettsiemia 踺明等に低り本病を確認され， 抗生物質 (Chloromycetin 6. 25 6.50g, Terramycin 3.5 10.0g, Leucomycin 6.75g) 投与飞估り登病 早期々解熱し了つた被検者 10 名に，マウス腹膑内接㼛 titration により力価既知の同一侏病毒の1 $10^{-1 \sim-4} 0.1$ $\mathrm{ml}$ 前腕屈側中央部皮内に攻謷再荄種した。この際同 時に同接種材料を，既に定琹的発病を経過し强圆な免 疫を有ずる挝過者及び恙虫病の経験の無い者に全く同 㥞に接種し，前者を免没対照，後者を非免疫対照とし て夫々の発病の有無を観察した。

病毒接種後の観察期間を一応 3 週間（発病した場合 は解熱後更に 3 週間) とし，その間は每日4〜8回（発 熱期間中は 8 回) の腋裔検温を行つて発熱の有無，程 度等を追求した。文, 接種後種々の時期々摇血し, 光 导マウス腹腔内に接種し，3代迄累代して rickettsiemiaの有想を検し，更に接種前及び観察期間経過後の

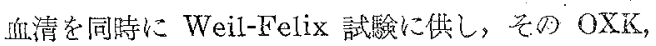
OX19 血清凝集価上昇の有無を倹した。その他の蹦床 症状としては，接種局処の特筫的皮膚反応，リンパ節

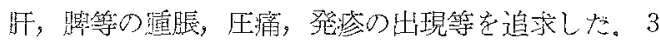
週間の観察期閵後も被検者の状態には常に注意意ら なかつたが，此の観察期間経過後に発病を来寸事は絶 刘に無かつた。

\section{実 験 結 果}

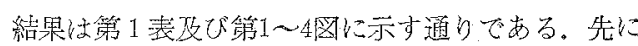

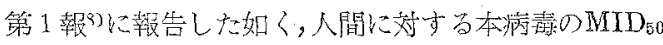
$(0.1 \mathrm{ml}$ 度内 $)$ は，マウス $\mathrm{LD}_{50}(0.3 \mathrm{~m} 1$ 腹腔内 $) に 一$ 致する事代碓められて居る。又，Ley 等15）も别途に Gilliam, Karp, CP-14 株等に就き同椂の結果を報告

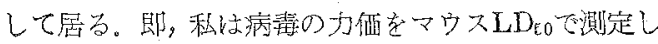
た分以下之を人間に効する $\mathrm{MID}_{50}$ として婊現する。

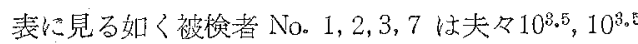
$10^{3.5}, 10^{2.9} \times \mathrm{MID}_{50}$ の病毒の0.1 m1 皮内接種に依り攻撃 された。即，此較的少量の病瑇炼接種を受けた。此の 場合，表及び図に見る如く同じ接種を受けた非免疫対

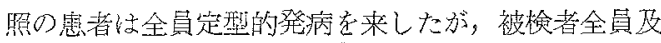
び免疫刘照の患者は全員全く反応を示さず，発熱は勿 䜊乥の他の一切の臨秝症状の発呈なく, rickettsiem-

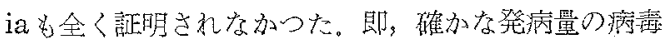
の政馨に対し完全な抵抗を示した。No.4，5，6，8，9， 100 の被檢者は夫多 $10^{5.5}, 10^{5.5}, 10^{5.9}, 10^{6.7}, 10^{6.7}, 10^{6.7} \times$

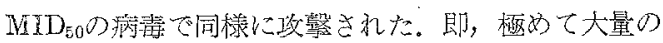
病毒の再接種を受故た。此の場合も非免疫対照注勿論 定型的に発病を来したが，を等の被検者及び色疫刘照 は前記の場合と全く同様に何等の变化も示さなかつ

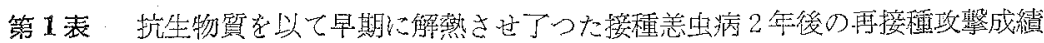

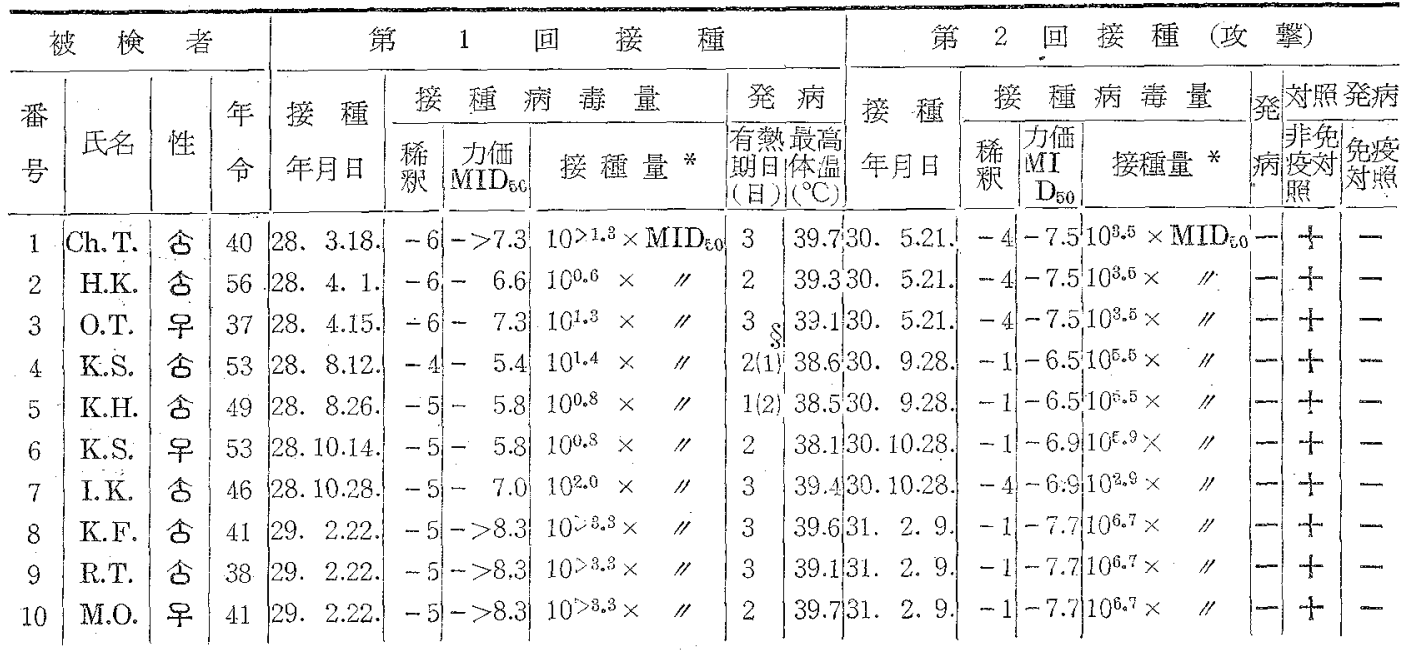
* $0.1 \mathrm{ml}$ 皮内接種
§括泒内再登期間 
当1 四

No.1

Ch.T.

合 $40 \mathrm{t}$

No.2

H. K.

今े $56 t$

No.3

O.T.

$+37 \%$

非急疫䇃照

T. K.

早 55

急㾌站照

S.K.

i 414

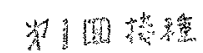

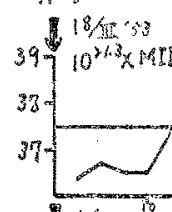

R: RIEKETtStEmats

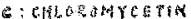

$r: T E R R A M Y C I N$
河只困接穆

$2 i / 5 \cdot 5$

$10^{3.5} \times \mathrm{MSD}_{30}$

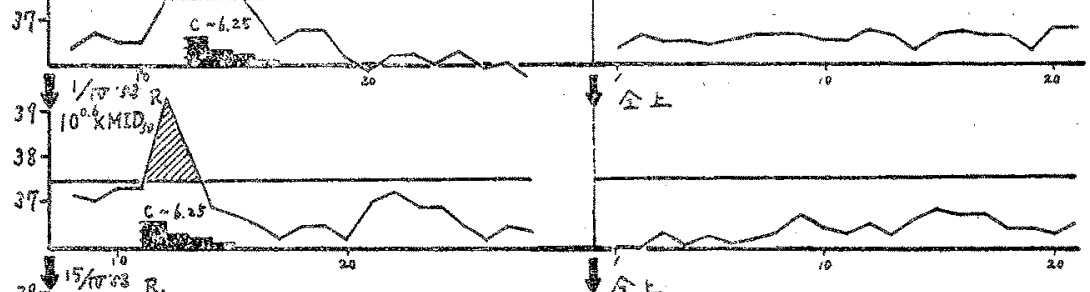
伎盟

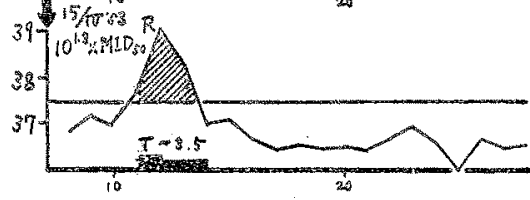

会上

接稳後

牙2

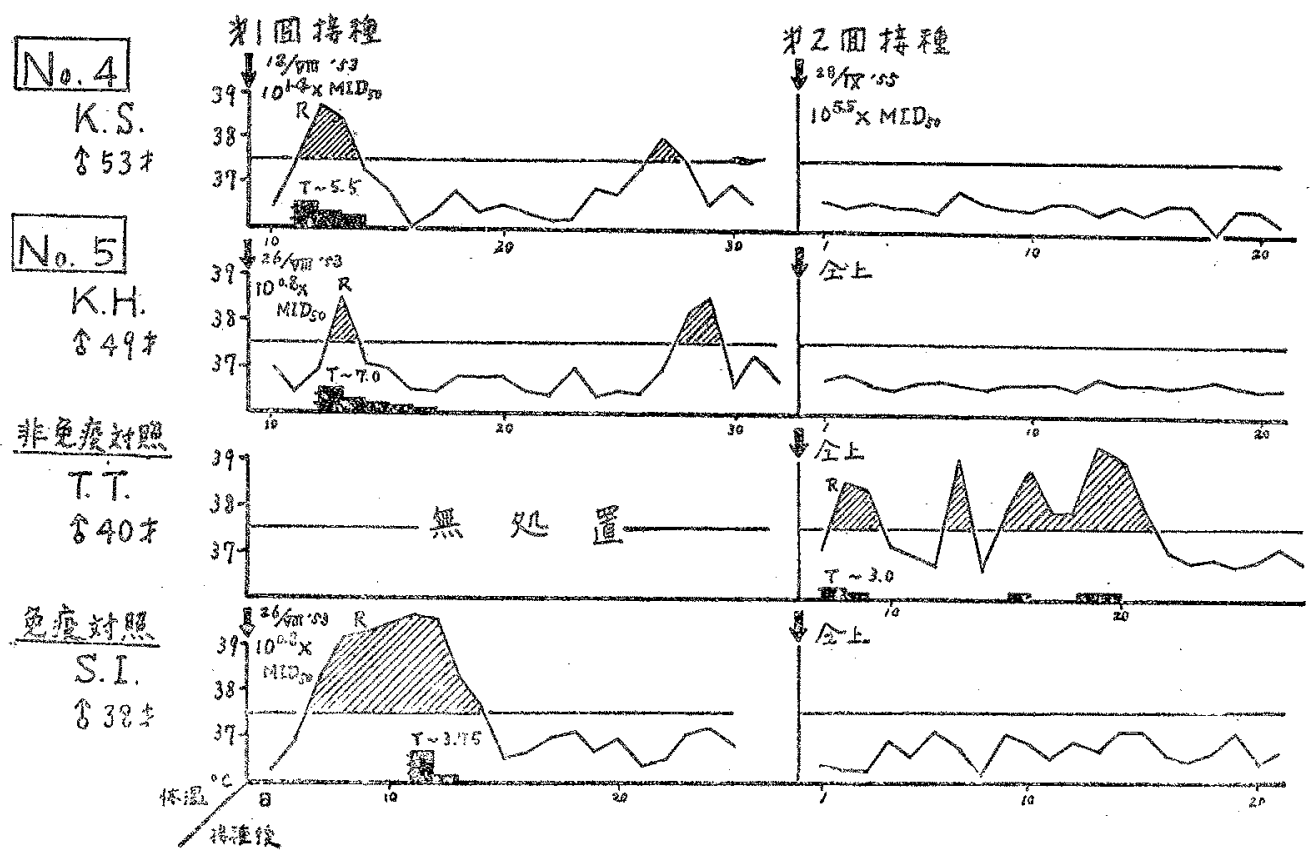


决了四

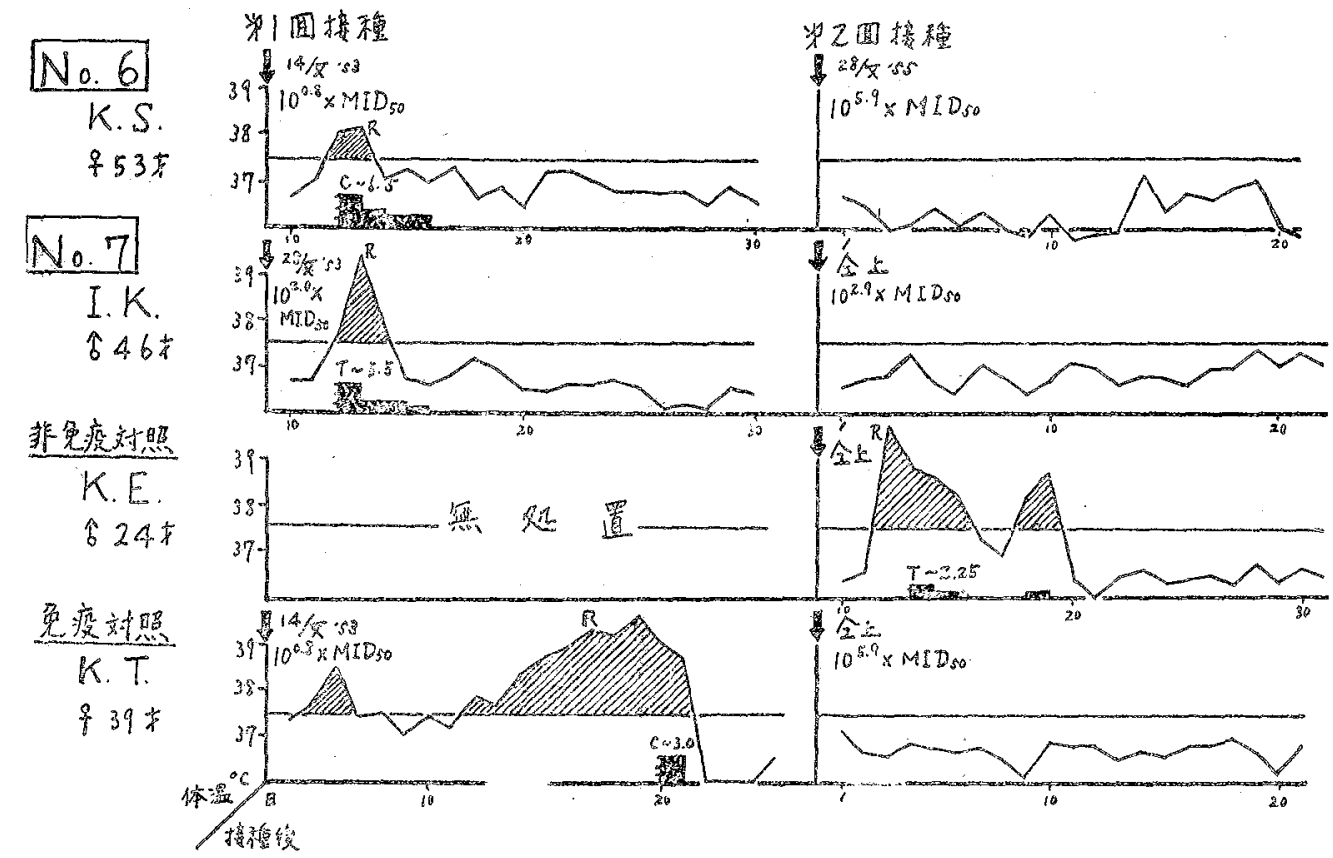

为4 四

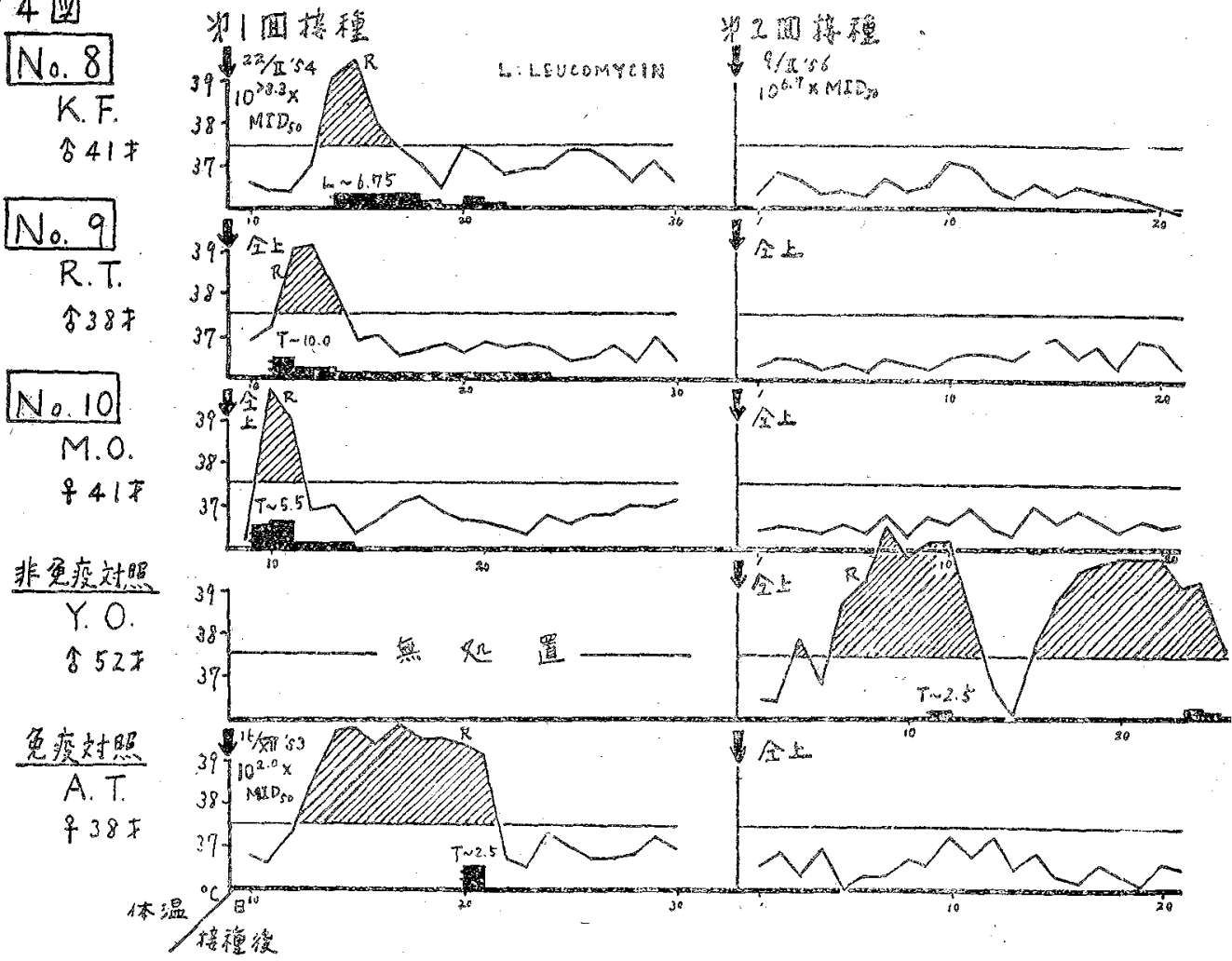




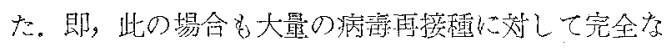
抵抗を示した。

第1 表及び第1 4 图に見られる逼り，既往発病時の

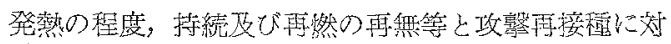
する抵抗の強さとの間には全く相関性为見られず，病

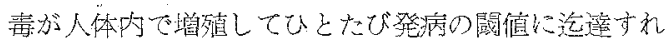

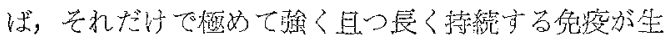
成されることが解つた。

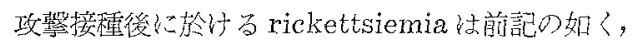

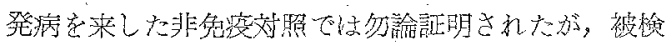
者及び免疫対照に於いては全然証明出来学かつた。即， 第 2 表に示す通りである。又，此の表に見る如く，非

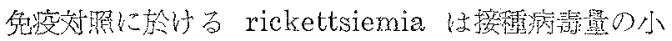
なる時は掘く，大なる時は早く出現する。蓋し，侵入 病毒が体内で增殖して rickettsiemia 来す闌倠に过

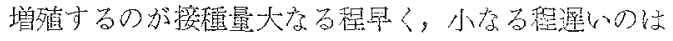
当然であう。

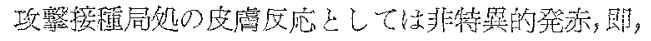

接種材料中に含まれる異種蛋白（マウス畈乳剂にによ る一過性発亦吢全例に思られるが，之注数日にして消

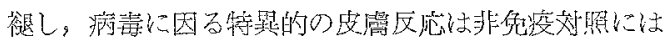
定型的に表初れたが，被检者及び筧疫效照には全く見 られなかつた。

尚，既に第1䜷に於いてその一部の成績に就いては

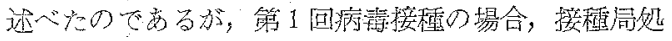

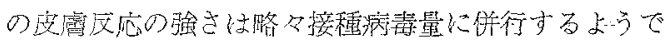

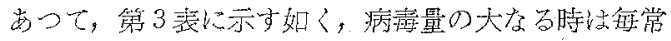

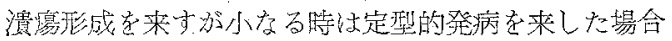

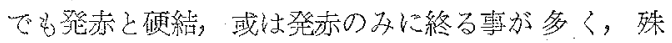
に，全く局処の特異的度覷反応を欠如して定型的発病

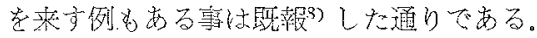

その他の症状，即，発疹の出現，リンパ節，殊に接

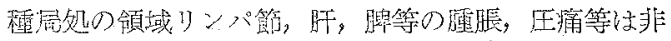

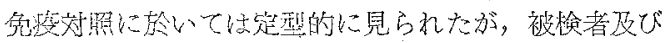

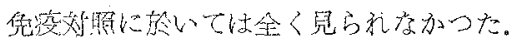

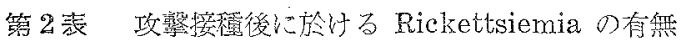

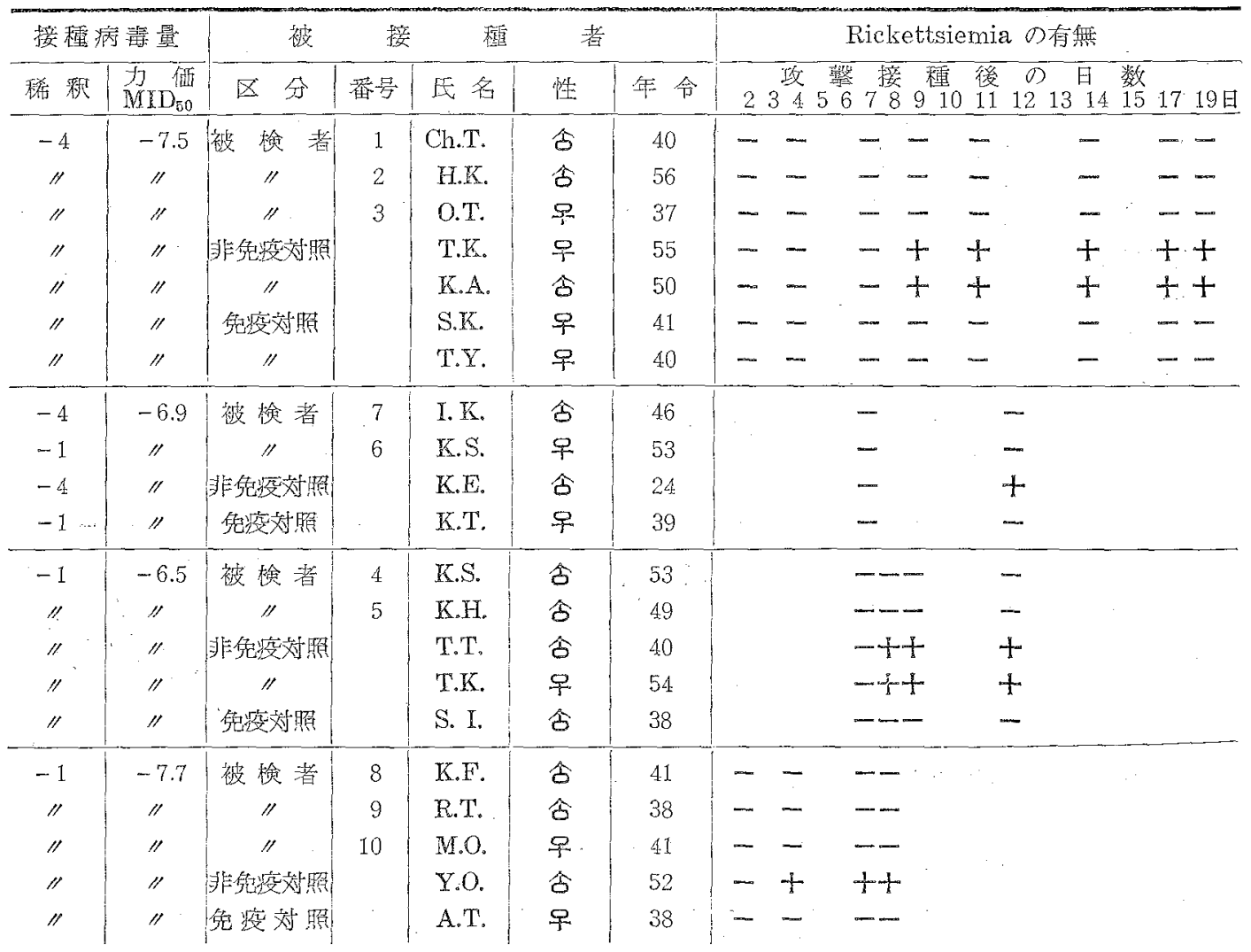




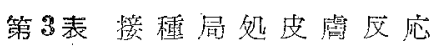

\begin{tabular}{|c|c|c|c|c|c|c|}
\hline \multirow{2}{*}{\multicolumn{2}{|c|}{$\begin{array}{l}\text { 艾盧反 } \\
\text { 灾程度 }\end{array}$}} & \multicolumn{3}{|c|}{ 接 現 病 青量 } & \multicolumn{2}{|c|}{ 例 数 } \\
\hline & & 稀积 & $\operatorname{MID}_{\tilde{\Sigma} 0}$ & 接 種 量* & 小計 & 計 \\
\hline & 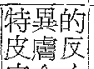 & & -7.4 & $10^{2.4} \times \mathrm{MLD}_{\varepsilon 0}$ & & 2 \\
\hline & 究全人 & -5 & $->7.4$ & $10>2.4 \times 11$ & 1 & \\
\hline \multirow{4}{*}{+} & 発 & -5 & -5.8 & $10^{0.3} \times \mathrm{MID}_{\varepsilon 0}$ & 3 & \\
\hline & 赤 & -5 & -7.5 & $10^{2.5} \times$ & 1 & 6 \\
\hline & $\begin{array}{l}9 \\
2\end{array}$ & -5 & $->8.3$ & $10>3.3 \times$ & 1 & \\
\hline & & -4 & -6.9 & $10^{2.9} \times$ & 1 & \\
\hline \multirow{10}{*}{ H. } & & -7 & -7.0 & $1 \times \mathrm{MID}_{.0}$ & 1 & \\
\hline & 発 & -6 & -65 & $10^{0.6 \times} / 11$ & 1 & \\
\hline & & -6 & $->7.3$ & $10^{>1.3} \times 11$ & 1 & \\
\hline & 赤 & -5 & $-\quad 5.8$ & $10^{0.3} \times 11$ & 3 & \\
\hline & & -5 & -7.0 & $10^{2.0} \times 11$ & 2 & 13 \\
\hline & 硬 & -5 & -7.4 & $10^{2.4} \times \quad 11$ & 1 & \\
\hline & & -4 & $-\quad 5.4$ & $10^{1.4} \times \quad / 1$ & 1 & \\
\hline & 絬 & -4 & $-\quad 5.6$ & $10^{1.6} \times \quad 11$ & 1 & \\
\hline & & -4 & -6.6 & $10^{2.6} \times$ & 1 & \\
\hline & & -4 & -7.5 & $10^{3.5} \times$ & 1 & \\
\hline \multirow{11}{*}{ H } & & -5 & -5.8 & $10^{0.8} \times M D_{\varepsilon 0}$ & 1 & \\
\hline & 潰 & -5 & $->8.3$ & $10^{>3.3 \times} \times 11$ & 1 & \\
\hline & & -1 & -5.8 & $10^{4.8} \times \quad 11$ & 3 & \\
\hline & 谤 & -1 & -6.2 & $10^{5.2} \times 1 /$ & 2 & \\
\hline & & -1 & -6.5 & $10^{5.5} \times \quad 11$ & 4. & 30 \\
\hline & 形 & -1 & $-\quad 6.7$ & $10^{E .7} \times 11$ & 2 & \\
\hline & & -1 & -7.0 & $10^{6.0} \times$ & 5 & \\
\hline & 成 & -1 & -7.2 & $10^{6.2} \times$ & 4 & \\
\hline & & -1 & $-\quad 7.6$ & $10^{6.6} \times \quad 11$ & 2 & \\
\hline & & -1 & $-\quad 7.7$ & $10^{6.7} \times \|$ & 1 & \\
\hline & & -1 & -6.9 & $10^{E .9} \times$ & $5 \$$ & \\
\hline
\end{tabular}

第 1 回病毒接種に因り発病した際，発熱持続期間の 長い場合には之の後の OXK 血清凝集政の上昇が著し く，㛒い場合には㱠んぞ上暑が見られず，此の闭者間

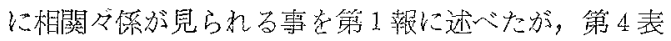
に示す如く，非免疫対照及び色疫対照の発㾈の際には 発熱持続は充分に長いので OXK 血清凝集価は著しく 上昇して殒る。その反面，被検者に於いては第 1 回接 種に因当発熱㥀ちに㙰熱させられて居るので㠜集価

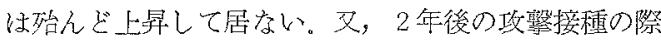

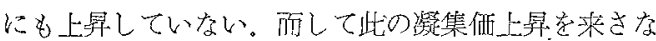

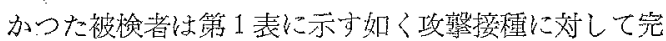

全な抵抗を示し效病を来さなかつた者である。即，必

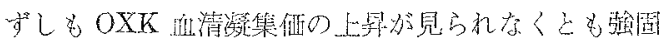
な免疫は成立し得るのである。

\section{答察}

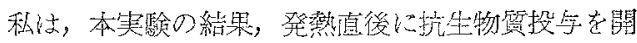

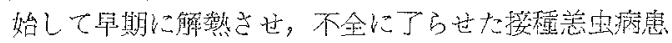

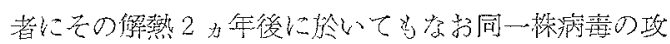

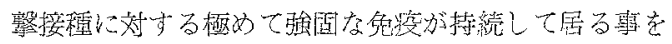
知り得た。

既《10数年前に斤村9)，西成田(6)，上村17) 等によつ て本病表接種例に於外る色疫特続に就いて報告されて いるが，其等の例はすがて定型的発病意経過したもの であつて本実験の例と法全々買る。亦，当時として站

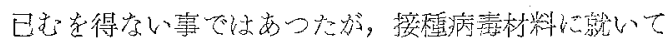

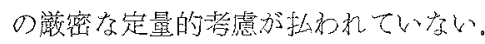

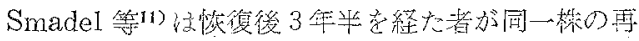

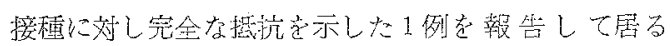

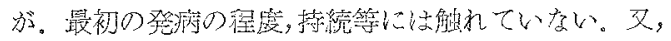

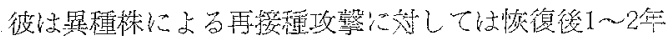

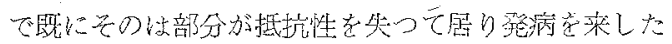

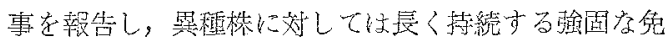
疫を与えることが固難で亦る事を示唆して居る。

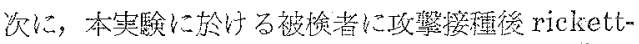

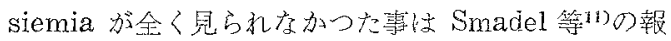

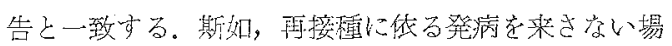
合には，接種局処の皮膚反応も，rickettsiemia \& 見

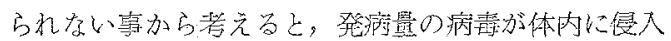

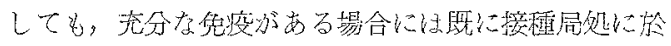
いて血清抗体に依り不活化されて仕舞うものと想像さ れるのであつて，恙虫病に於いても亦，当然の事なが ら，接種病清に対し不活化的に作用する血清抗体の臬 接作用，更々文，之と所謂 prémunition 当免疫の 本熊との関連性に就いて尚一段の解析㤂なさるべきで あると考光る。

最初の病毒接種に因る OXK 血清凝集何の上界喥と 攻撃接種に対卞る抵抗の强さとの間に相関的関係壮見 られない。即，第1報に述べた如く，発熱後直ちに抗 生物質投与を開始して早期に解熱させ了つた例では O

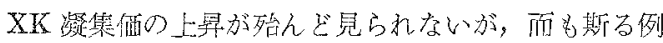

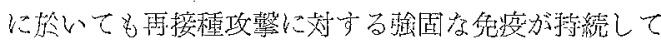
居る事实よりすると，强国考免疫の獲得には，OXK 血清凝集伴の顕著な上景注必ずしも不可欠のもので注 


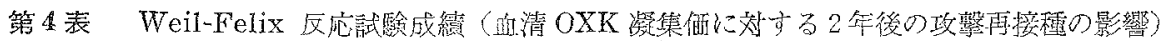

\begin{tabular}{|c|c|c|c|c|c|c|c|c|c|c|}
\hline 被 & 種 & 者 & & o & $\mathrm{K}$ & & & $\mathrm{O}$ & 19 & \\
\hline \multirow{2}{*}{ 区 分 } & \multirow{2}{*}{ 萫 号 } & \multirow{2}{*}{ 䐆 } & \multicolumn{2}{|c|}{ 第 1 回接種 } & \multicolumn{2}{|c|}{ 策 2 回接種 } & \multicolumn{2}{|c|}{ 第 1 回接種 } & \multicolumn{2}{|c|}{ 第 2 回接種 } \\
\hline & & & 接種前 & 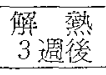 & 接福前 & 接種" & 接種前 & 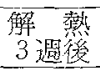 & 接種前 & 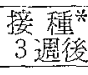 \\
\hline \multirow{2}{*}{ 被 梌 者 } & 1 & Ch. T. & $<20$ & 40 & 40 & $<40$ & 40 & 40 & 40 & $<40$ \\
\hline & 2 & $\mathrm{H} . \mathrm{K}$. & $<20$ & 40 & 40 & 40 & $<20$ & 20 & $<40$ & $<40$ \\
\hline \multirow{3}{*}{$\begin{array}{c}\text { " 非免疫対照 } \\
\text { " }\end{array}$} & 3 & O. T. & $<40$ & 40 & 40 & 40 & 40 & 40 & $<40$ & 40 \\
\hline & & T. K. & - & - & 40 & 320 & - & - & 40 & 40 \\
\hline & & K. A. & $\ldots$ & - & $<40$ & 160 & - & - & $<40$ & 4.0 \\
\hline \multirow{2}{*}{$\begin{array}{c}\text { 免疫対照 } \\
\text { " }\end{array}$} & & S. K. & 40 & 320 & 80 & 80 & $<20$ & $<20$ & $<40$ & $<40$ \\
\hline & & T. Y. & 40 & 160 & 160 & 160 & 80 & 160 & 80 & $<40$ \\
\hline \multirow{5}{*}{ 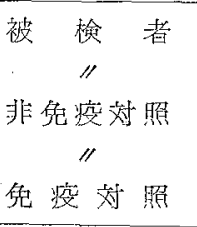 } & 4 & K. S. & $<20$ & 40 & 40 & 40 & 20 & 40 & 40 & 40 \\
\hline & 5 & K. H. & 40 & 80 & 80 & 80 & $<20$ & $<20$ & 80 & 80 \\
\hline & & T. T. & - & - & 80 & 320 & - & $\ldots$ & 40 & 80 \\
\hline & & T. K. & - & $-m$ & 40 & 320 & - & - & 40 & 80 \\
\hline & & S. I. & 20 & 160 & 160 & 160 & 40 & 40 & 80 & 80 \\
\hline \multirow{4}{*}{ 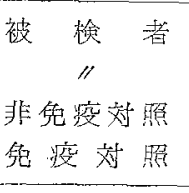 } & 6 & K. S. & 40 & 80 & 80 & 80 & $<20$ & $<20$ & 80 & 80 \\
\hline & 7 & I. $\mathrm{K}$. & 40 & 40 & 80 & 80 & 20 & 40 & 80 & $<40$ \\
\hline & & K. E. & $\cdots$ & $\cdots$ & $<40$ & 160 & - & - & $<40$ & 40 \\
\hline & & K. T. & 20 & 320 & 160 & 80 & 20 & 20 & 80 & 80 \\
\hline \multirow{5}{*}{$\begin{array}{c}\text { 被 検者 } \\
\text { " } \\
\text { " 非免疫対照 } \\
\text { 免疫対照 }\end{array}$} & 8 & K. F. & $<40$ & 40 & 40 & 40 & $<40$ & $<40$ & 80 & 80 \\
\hline & 9 & R. T. & 80 & 80 & 40 & 40 & $<40$ & $<40$ & $<40$ & $<40$ \\
\hline & 10 & M. $O$. & $<40$ & 40 & 40 & 40 & $<0$ & $<40$ & $<40$ & $<40$ \\
\hline & & Y. O. & - & - & $<40$ & 80 & - & - & $<40$ & $<40$ \\
\hline & & A. T. & 20 & $>640$ & 80 & 80 & $<20$ & $<20$ & $<40$ & $<40$ \\
\hline
\end{tabular}

* 非免疫対照注解熱 3 週後

ないと考えられる。

総 括

人体に澎湖島株恙虫病々毒を接種して発病させ，発 熱するや直ちに抗生物質投与を開始して速加に解熱さ せ全く不全型に了らせた場合でも徐堛な免疫が生成さ れ，2年経過後も，同一株の大量再接種に刘して完全 に耐元る強固な免疫分持続して居る。又，Weil-Felix 区応，OXK 血清凝集価の上昇度とその後住生成され る免疫の强さとの間には相関的関係は存在しない. 又, 病毒接種局処の皮膚反応の強さ注略及接種病毒量 に作行するが，時に全く之を尔如して発病艾来守事も 岁。

御指導と御校闑を賜つた研究部長，林慄愽士に深く 感謝致します。

尚，精神医学研究所多長，荘筧博上，副所長，上田
守長博士の御䩒挂と，同附属病院副院唇，未弘乾博 士，医長，橋村秋雄博士友び医員各位の御支援とに 感謝致します。

\section{交献}

1）【几村䚬也，伊藤辰治，中村隆治，上村忠雄，佐藤 猪久彦: 恙虫病の予防に就いて(第 1 報)：日本医事 新報，754号，697 700，1937. 2) Smadel, J.E., Ley, H. L., Jr., Diercks, F. H., Traub, R., Tipton, V. T. \& Frick, L. P.: Immunization against scrub typhus. I. Combined living vaccine and chemoprophylaxis in volunteers.: Amer. Joux. Hyg., 53, 317-325, $1951 . \quad 3)$ Philip. C. B., Traub, R. \& Smadel, J. E. : Chloramphenicol (Chloromycetin) in the chemoprophylaxis of scrub typhus (Tsutsugamushi disease). I. Epidemiological observations on hyperendemic areas of scrub typhus in Malaya.: Amer. Jour. Hyg., 50, 63-74, $1949 . \quad$ 4) Smadel, J. E.; 
Traub, R., Ley, H. L., Jr., Philip, C. B., Woodward, T. E. \& Lewthwaite, R.: Chloramphenicol (Chloromycetin) in the chemoprophylaxis of scrub typhus (Tsutsugamushi disease). II. Results with volunteers exposed in hyperendemic areas of scrub typhus.: Amer. Jour. Hyg,, 50, 75-91, 1949. 5) Smade1, J. E., Traub, R., Frick, L. P., Diercks, F. H. \& Bailey, C. A.: Chloramphenicol (Chloromycetin) in the chemoprophylaxis of scrub typhus (Tsutsugamushi disease). III. Suppression of overt disease by prophylactic regimens of four-week duration.: Amer. Jour. Hyg., 51, 216-228, 1950.6$)$ Smadel, J. E., Bailey, C. A. \& Diercks, F. H.: Chloramphenicol (Chloromycetin) in the chemoprophylaxis of serub typhus (Tsutsugamushi disease). IV. Relapses of scrub typhus in treated volunteers and their prevention.: Amer. Jour. Hyg., 51, 229-241, 1950.7 7) Traub, R. \& Frick, L. P.: Chloramphenicol (Chloromycetin) in the chemoprophylaxis of scrub typhus (Tsutsugamushi disease). V. Relation of number of vector mites in hyperendemic areas to infection rates in exposed volunteers: Amer. Jour. Hyg., 51, 242 247, 1950. 8) 中村

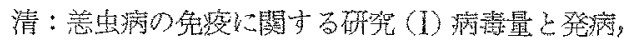
更に免疫との関係に就いて：VIRUS, 4, 198〜203, 1954.99）川1村䚬也，笠原四郎，外山富雄，西成

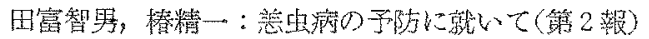

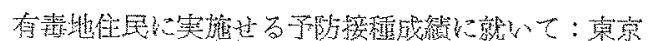

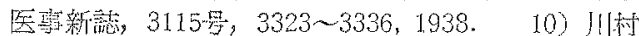

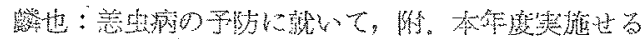

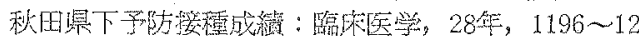
05, 1940. 11) Smadel, J. E., Ley, H. L., Jr., Diercks, F. H. \& Traub, R.: Immunity in serub typhus.: Resistance to induced reinfection.: Arch. Path., 50, 847-861, 1950.1 12) Ley, H. L., Jx., Diercks, F. H., Paterson, P. Y., Smadel, J. E., Wissemann, C. L., Ir. \& Traub, R.: Immunization against scrub typhus. VI. Living Karp vaccine and chemoprophylaxis in volunteers. : Amer. Jour. Hyg., 56, 303-312,

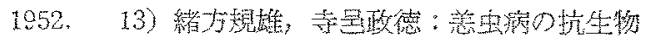

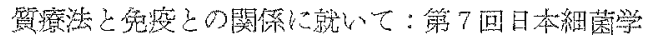

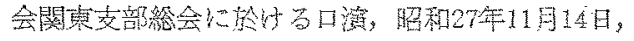
1952. 14) Kawamura, R. \& Yamamiya, Ch.: On the Tsutsugamushi disease in the Pescadores.: Kitasato Arch. Exp. Med. 16, 1, 79-91, 1939. 15) Ley, H.L., Jr., Snadel, J. E., Diercks, F. H. \& Paterson, P. Y.: Immunization against scrub typhus. $V$. The infective dose of Rickettsia tsutsugamushi for men and mice.: Amer. Jour. Hyg., 56, 313-319, 1952. 16) 西

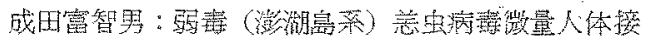
種认よる售崚の獾得：日本医学，3382号，12〜15,

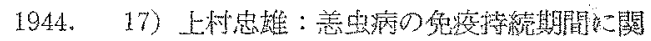

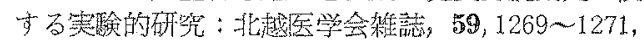
1944 . 